\title{
Consumer involvement profiles: An application of consumer involvement in mobile industry
}

\author{
Homa Rahbarian $^{\mathrm{a}^{*}}$ and Fattaneh Alizadeh Meshkani ${ }^{\mathrm{b}}$
}

${ }^{a}$ Department of Management, United Arab Emirates International Branch, Islamic Azad University, Tehran, Iran

${ }^{b}$ Department of Management and Accounting, South Tehran Branch, Islamic Azad University, Tehran, Iran

\section{H R O N I C L E}

Article history:

Received July 28, 2013

Accepted 14 January 2014

Available online

February 272014

Keywords:

Consumer involvement

Involvement profile

Mobile industry

\section{A B S T R A C T}

This paper investigates consumer involvement profile among people who intend to purchase mobile devises. The study considers the effects of various factors influencing on purchase intention including consumers' personal characteristics such as age, gender, income as well as some external factors including advertisement. The study uses a questionnaire in Likert scale, originally developed by O'Cass (2000) [O'Cass, A. (2000). An assessment of consumers' product, purchase decision, advertising and consumption involvement in fashion clothing. Journal of Economic Psychology, 21, 545-576.]. The questionnaire has been distributed among 385 people, randomly who purchased mobile devices from a mall in city of Tehran, Iran. Using Pearson correlation test, the study has concluded that oral advertisement as well as consumer purchase involvement have positive and strong relationship with consumer's purchase intention. In terms of age, people aged 20-30 maintained the highest purchase intention. In addition, in terms of gender, men had more purchase involvement than women did.

\section{Introduction}

The drive to learn the purchasing and consumption behavior of individuals and market segments has generated substantial interest in the construct of involvement (Zaichkowsky, 1985). O'Cass (2000) examined four kinds of involvement including product involvement; purchase decision involvement; advertising involvement and consumption involvement. The author proposed a higher order construct named consumer involvement and examined all four types of involvement using CFA and structural equation modelling (SEM). The author studied the impact of materialism and self-image productimage congruency on consumers' involvement in fashion clothing by looking into purchase decision involvement, subjective fashion knowledge and consumer confidence (O'Cass, 2004). The study indicates that fashion clothing involvement was substantially influenced by a consumer's degree of materialism, age and gender. The study also detected that fashion clothing involvement impacted fashion clothing knowledge and fashion clothing knowledge impacted consumer confidence in making purchase decisions about fashion. Dholakia (2001) presented a conceptual motivational

*Corresponding author.

E-mail addresses: h.rahbarian@yahoo.com (H. Rahbarian) 
process model, investigating the processes by which involvement and consumer risk perceptions were caused, and impact one another, as well as subsequent behavioral responses of consumers. Kim (2005) performed an investigation to find out more on how consumers may be segmented based on their levels of apparel product involvement using Laurent and Kapferer's consumer involvement profiles (CIP). They examined whether consumers within each profile group could be differentiated by their personally-held values. The study reported that values could be applied to further explain differences between the enthusiast and moderate consumer types. Chiang and $\mathrm{Yu}$ (2010) performed a survey on female consumer behavior in cosmetics market case study of female consumers in Hsinchu Area Taiwan.

\section{The proposed study}

This paper investigates consumer involvement profile among people who intend to purchase mobile devises. The study considers the effects of various factors influencing on purchase intention including consumers' personal characteristics such as age, gender, income as well as some external factors including advertisement. The study uses a questionnaire in Likert scale, originally developed by O'Cass (2000, 2004) and Khare and Rakesh (2010). The study considers the following six hypotheses, which are also shown in Fig. 1.

1. There is a positive relationship between product involvement and product involvement in using mobile devices.

2. There is a positive relationship between consumer purchase intention and product involvement in using mobile devices.

3. There is a positive relationship between advertising involvement and product involvement in using mobile devices.

4. Product involvement among women is higher than men's involvement.

5. Product involvement among young people is higher than older.

6. Product involvement among rich people is higher than poor.

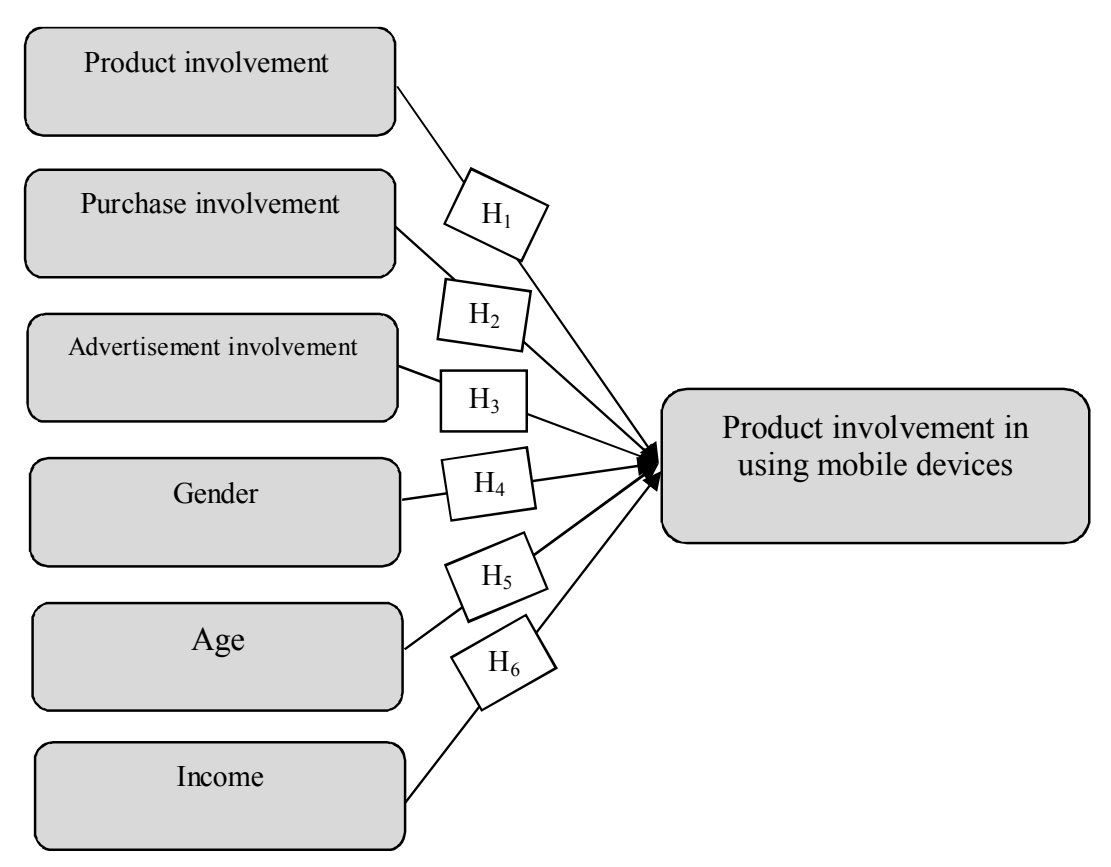

Fig. 1. The proposed study 
The proposed study has applied Kolmogorov-Smirnov test and the results have confirmed that all data were normally distributed. Therefore, we use Pearson correlation test to examine different hypotheses of the survey. In addition, Table 1 shows details of Kaiser-Meyer-Olkin (KMO) Measure of Sampling Adequacy and Bartlett's Test of Sphericity have been performed to validate the results and they both validated the questionnaire.

Table 1

The summary of KMO and Bartlett's Test

\begin{tabular}{ccc}
\hline KMO & & 0.89 \\
\hline & Maximum Chi-Square & 163.04 \\
Bartlett's Test & df & 384 \\
& Sig. & 0.000 \\
\hline
\end{tabular}

\section{The results}

In this section, we present details of our investigation to examine different hypotheses of the survey. Table 2 shows details of Pearson correlation test on examining hypothesis 1 to hypothesis 3 .

\section{Table 2}

The results of Pearson correlation test

\begin{tabular}{lcccc}
\hline Hypothesis & Number of questions & Pearson & Sig. & Result \\
\hline First & 385 & 0.826 & 0.000 & Confirmed \\
Second & 385 & 0.867 & 0.000 & Confirmed \\
Third & 385 & 0.884 & 0.001 & Confirmed \\
\hline
\end{tabular}

As we can observe from the results of Table 2, the first three hypotheses of the survey have been confirmed through Pearson correlation test. There is a positive relationship between product involvement and product involvement in using mobile devices. In addition, there is a positive relationship between consumer purchase intention and product involvement in using mobile devices. Finally, there is a positive relationship between advertising involvement and product involvement in using mobile devices. In order to examine the fourth hypothesis of the survey we use analysis of variance (ANOVA) test. Table 3 shows details of the results of ANOVA test to see whether there is any difference between men and women on product involvement in using mobile devices.

Table 3

The summary of the results of ANOVA test

\begin{tabular}{lccccccc}
\hline Dependent variable & Gender & Mean & F & df & Sig. & Confidence level & t-value \\
\hline Product involvement & Men & $12.3^{*}$ & 9.418 & 204 & 0.000 & 0.96 & 2.661 \\
& Women & 12.1 & & 177 & & \\
\end{tabular}

As we can observe from the results of Table 3, there is a significance difference between two groups in terms of their product involvement in using mobile devices.

In order to examine the fifth hypothesis of the survey, we define four groups aged 20-30, 30-40, 4050 and $>50$. Let $\mu_{1}$ to $\mu_{4}$ be the mean of the first to fourth group, respectively. Therefore, we examine the following hypothesis,

$$
\begin{cases}H_{0}: \quad \mu_{1}=\mu_{2}=\mu_{3}=\mu_{4} \\ H_{1}: \quad \text { At least two groups have different mean }\end{cases}
$$

Table 4 shows details of our survey on testing the fifth hypothesis. 
Table 4

The results of testing the effect of age on product involvement in using mobile devices

\begin{tabular}{lccccc}
\hline & Sum of Squares & df & Mean of Squares & F-value & Sig. \\
\hline Inside group & 733.274 & 4 & 146.655 & 4.601 & 0.001 \\
Between group & 1976.417 & 266 & 31.878 & & \\
\hline & 2709.691 & 67 & & & \\
\hline
\end{tabular}

The results of Table 4 show that there is a meaningful difference between different groups of people in terms of age. Our further investigation indicates that younger people are more concern in product involvement in using mobile devices. To examine the last hypothesis of the survey, we have performed similar group classification in terms of income from low income to high income in four groups. Table 5 shows details of our investigation.

\section{Table 4}

The results of testing the effect of income on product involvement in using mobile devices

\begin{tabular}{lccccc}
\hline & Sum of Squares & df & Mean of Squares & F-value & Sig. \\
\hline Inside group & 733.274 & 4 & 146.655 & 4.601 & 0.001 \\
Between group & 1976.417 & 266 & 31.878 & & \\
\hline & 2709.691 & 67 & & & \\
\hline
\end{tabular}

Similarly, we can see that there was a meaningful difference between people with various incomes.

\section{Conclusion}

In this paper, we have presented an empirical investigation to find out more the effects of various factors influencing on product involvement in using mobile devices. The results have indicated that there was a positive relationship between product involvement and product involvement in using mobile devices. In addition, there was a positive relationship between consumer purchase intention and product involvement in using mobile devices. Finally, there was a positive relationship between advertising involvement and product involvement in using mobile devices. In our survey middle aged people and people with average income have more product involvement.

\section{References}

Chiang, C. T., \& Yu, W. C. (2010). Research of female consumer behavior in cosmetics market case study of female consumers in Hsinchu Area Taiwan. Communications \& Network, 2(4).

Dholakia, U. M. (2001). A motivational process model of product involvement and consumer risk perception. European Journal of marketing, 35(11/12), 1340-1362.

Kim, H. S. (2005). Consumer profiles of apparel product involvement and values. Journal of Fashion Marketing and Management, 9(2), 207-220.

Khare, A., \& Rakesh, S. (2010). Predictors of fashion clothing involvement among Indian youth. Journal of Targeting, Measurement and Analysis for marketing, 18(3), 209-220.

Laurent, G., \& Kapferer, J. N. (1985). Measuring consumer involvement profiles. Journal of Marketing Research (JMR), 22(1).

O'Cass, A. (2000). An assessment of consumers' product, purchase decision, advertising and consumption involvement in fashion clothing. Journal of Economic Psychology, 21, 545-576.

O'Cass, A. (2004). Fashion clothing consumption: antecedents and consequences of fashion clothing involvement. European Journal of Marketing, 38(7), 869-882.

Zaichkowsky, J. L. (1985). Measuring the involvement construct. Journal of Consumer Research, 12(3), 341. 